\title{
ADVANCED LOWER URINARY OBSTRUCTION IN CHILDHOOD*
}

\author{
BY \\ P. P. RICKHAM \\ From Alder Hey Children's Hospital, and the Royal Liverpool Children's Hospital
}

During the past 10 or 12 years an increasing number of children with lower urinary obstruction have been admitted to hospital. American urologists have reported large series of children suffering from this condition (Baker, Tehan and Kelly, 1960; Deakin, 1957; Leadbetter and Leadbetter, 1959), but the majority of their cases suffered from minor degrees of obstruction without gross anatomical changes in the urinary tract. Many of these mild cases responded to medical treatment or simple urethral dilatation. In the series reported in this paper only those cases are included which had marked back pressure and definitive anatomical changes in the bladder as well as the upper urinary tract.

The signs, symptoms, diagnosis and treatment of the various conditions causing lower urinary obstruction in childhood are well known and will not be further discussed here. It is now widely realized that many cases are so advanced that after surgical removal of the obstruction complete recovery cannot be expected, and at best a moderate improvement is all that can be hoped for. In the past, however, it has not always been recognized that in many children the obstruction is of such an advanced degree that surgical extirpation of the obstructing lesion may be of no benefit. In these cases the bladder wall is fibrosed and numerous diverticula are present, the ureters are enormously dilated and tortuous and gross hydronephroses are present. In most cases the urine is heavily infected and renal function is often markedly deficient. Many of these children are first seen when they are in an advanced state of uraemia. If one attempts to remove the obstruction in the presence of such advanced lesions, the operative mortality is high. In those cases where the bladder has become a functionless bag, urinary infection and back pressure effects on the upper urinary tract will not improve, and further operations to promote adequate drainage of urine may be necessary.

\footnotetext{
* A paper read at a meeting of the British Association of Paediatric Surgeons in Stockholm, September 1961.
}

During the past 10 years 77 cases of lower urinary obstruction have been admitted to the surgical wards of the two Liverpool Children's Hospitals. In only 41 children was a primary removal of the obstruction successful. All survived and are greatly improved. They are now able to empty their bladders practically completely and are free from urinary infection. It must, however, be added that many still have varying degrees of hydronephroses, tortuous, dilated ureters and trabeculated bladders.

These 41 children we have called Group I, and they will not be further discussed in this paper. In Group II there were 28 children where, because of the advanced effects of back pressure, primary removal of the obstruction was out of the question. In Group III there were eight cases where primary removal of the obstruction was carried out, but this was found, in retrospect, to be an error of judgement. The children either succumbed or subsequent decompression operations became necessary. The children with advanced lower urinary obstruction in Groups II and III form the basis of this paper. The best that could be done for them was a decompression operation, relieving the abnormal pressure in the urinary system and draining away the urine. In most cases this decompression operation had to be a permanent affair. In some very select cases, it may be possible to remove the obstruction at a later date, when bladder and kidney function have sufficiently improved, and finally to reconstitute the normal anatomical conditions. It will be readily understood that the mortality in these two groups was high; 20 of the 36 children died; one death was not connected with the urinary tract lesion. The survivors can hardly be described as healthy individuals and are incapacitated to a greater or lesser degree. In the surgery of malformations of the urinary tract, as in those of the central nervous system, paediatric surgeons must resign themselves to the fact that many of their patients with advanced lesions will not recover completely.

A study of the fate of these advanced cases is, 
TABLE 1

NO SURGICAL TREATMENT ATTEMPTED

\begin{tabular}{|c|c|c|c|c|c|c|c|c|}
\hline Case & Sex & Age & $\begin{array}{l}\text { Presenting } \\
\text { Symptoms }\end{array}$ & $\begin{array}{l}\text { Blood Urea } \\
\text { (mg./100 ml.) }\end{array}$ & Infection & Pathology & Treatment & Follow-up \\
\hline 1 & Male & 11 days & Uraemia & 208 & $+++E \cdot$ coli & Valves & $\begin{array}{l}\text { Antibiotics, } \\
\text { intravenous }\end{array}$ & Death after three days \\
\hline 2 & Male & 6 weeks & $\begin{array}{c}\text { Urinary infec- } \\
\text { tion }\end{array}$ & 372 & $+++E$. coli & Valves & $\begin{array}{l}\text { Antibiotics, } \\
\text { intravenous }\end{array}$ & Death after two days \\
\hline 3 & Male & 1 day & $\begin{array}{l}\text { Anuria; absent } \\
\text { abdominal } \\
\text { muscles }\end{array}$ & 180 & None & $\begin{array}{l}\text { Atresia; anterior } \\
\text { urethra }\end{array}$ & None & Death after one day \\
\hline
\end{tabular}

TABLE 2

SUPRAPUBIC CYSTOSTOMY IN NEWBORN BABIES

\begin{tabular}{|c|c|c|c|c|c|c|c|c|}
\hline Case & Sex & Age & $\begin{array}{l}\text { Presenting } \\
\text { Symptoms }\end{array}$ & $\begin{array}{c}\text { Blood Urea } \\
\text { (mg./100 ml.) }\end{array}$ & Infection & Pathology & Treatment & Follow-up \\
\hline 4 & Male & 12 days & $\begin{array}{l}\text { Abdominal dis- } \\
\text { tension; } \\
\text { uraemia }\end{array}$ & 440 & + Proteus & 'Bladder neck' & Suprapubic & Anuria, death \\
\hline 5 & Male & 1 day & $\begin{array}{c}\text { Abdominal } \\
\text { distension }\end{array}$ & 24 & None & Valves & Suprapubic & $\begin{array}{l}\text { Pyelonephritis, } \\
\text { death }\end{array}$ \\
\hline 6 & Male & 1 day & $\begin{array}{c}\text { Anuria; abdomi- } \\
\text { nal distension }\end{array}$ & 42 & None & Valves & Suprapubic & Anuria, death \\
\hline 7 & Male & 2 days & $\begin{array}{l}\text { Abdominal dis- } \\
\text { tension; } \\
\text { dribbling }\end{array}$ & 46 & None & Valves & Suprapubic & $\begin{array}{l}\text { Pyelonephritis, } \\
\text { uraemia, death }\end{array}$ \\
\hline 8 & Male & 12 days & $\begin{array}{l}\text { Overflow incon- } \\
\text { tinence }\end{array}$ & 31 & +++ E. coli & Valves & Suprapubic & $\begin{array}{l}\text { Pyelonephritis, } \\
\text { uraemia, broncho- } \\
\text { pneumonia; death }\end{array}$ \\
\hline 9 & Male & $3 \frac{1}{2}$ weeks & $\begin{array}{l}\text { Dribbling; fail- } \\
\text { ure to thrive }\end{array}$ & 94 & +++ E. coli & Valves & Suprapubic & $\begin{array}{l}\text { No improvement; one } \\
\text { week later ureter- } \\
\text { ostomies; improve- } \\
\text { ment, but persistent } \\
\text { infect io ; f f u r } \\
\text { months later pyelo- } \\
\text { nephritis, septicae- } \\
\text { mia; death }\end{array}$ \\
\hline 10 & Male & 1 day & $\begin{array}{c}\text { Abdominal } \\
\text { distension }\end{array}$ & 31 & None & $\begin{array}{l}\text { Valves; intra- } \\
\text { uterine rup- } \\
\text { ture of blad- } \\
\text { der }\end{array}$ & $\begin{array}{l}\text { Suprapubic; } \\
\text { repair of rup- } \\
\text { ture }\end{array}$ & $\begin{array}{l}\text { Recovered; two weeks } \\
\text { later valves resec- } \\
\text { ted; well for six } \\
\text { years }\end{array}$ \\
\hline
\end{tabular}

therefore, a somewhat depressing affair. They are discussed here, partly to show the numerous mistakes which were made in their management, and partly because occasionally surprisingly satisfactory results could be achieved. The recuperation power of the urinary tract in infancy and childhood is truly amazing.

Group II can be further subdivided. Three very young infants were admitted in an advanced state of uraemia; no surgery was attempted. They died within a few days of admission. Autopsy showed that they had practically no functioning kidney tissue (Table 1).

The simplest type of decompression operation is undoubtedly suprapubic cystostomy, and this was carried out as a primary procedure in 16 children with advanced lower urinary obstruction. Seven were newborn babies (Table 2), where the obstruc- tion had produced grotesque dilatation of the urinary tract in utero with destruction of nearly all renal tissue (Figs. 1 and 2). Those who survived the first few days of life developed severe urinary infection. Five of them died, either of anuria or pyelonephritis, shortly after operation. In one patient the suprapubic cystostomy produced no improvement. Bilateral ureterostomies carried out within a week of the cystostomy improved the infant's general condition, but it was found impossible to eradicate the massive urinary infection and the child finally succumbed to pyelonephritis four months later. The only survivor in this group (Case 10) had the luck to rupture his enormously distended bladder in utero. At birth he suffered from gross abdominal distension with a large quantity of urine in his peritoneal cavity (Figs. 3 and 4). His ureters and renal pelves were only 


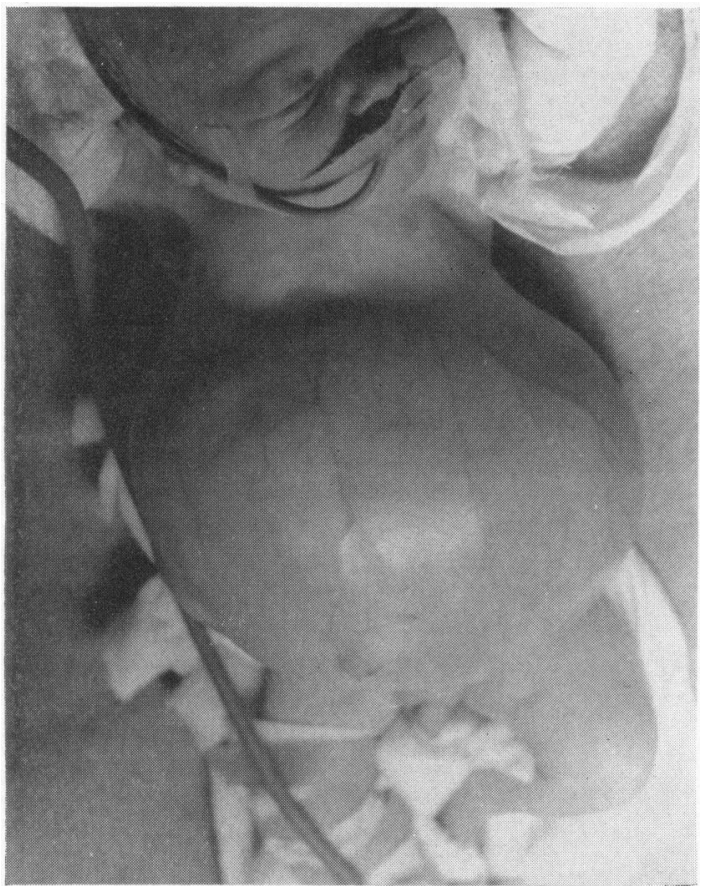

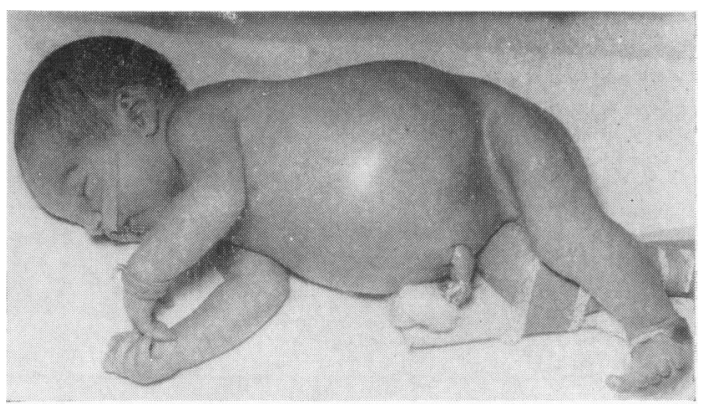

FIG. 3.

FIG. 1.-Case 5, shortly after birth, showing enormous abdominal distension due to hydronephrosis.

Fig. 2.-Case 5 at laparotomy, showing the enormous hydronephroses.

Fig. 3.-Abdominal distension at birth.

FIG. 1.

FIG. 2.

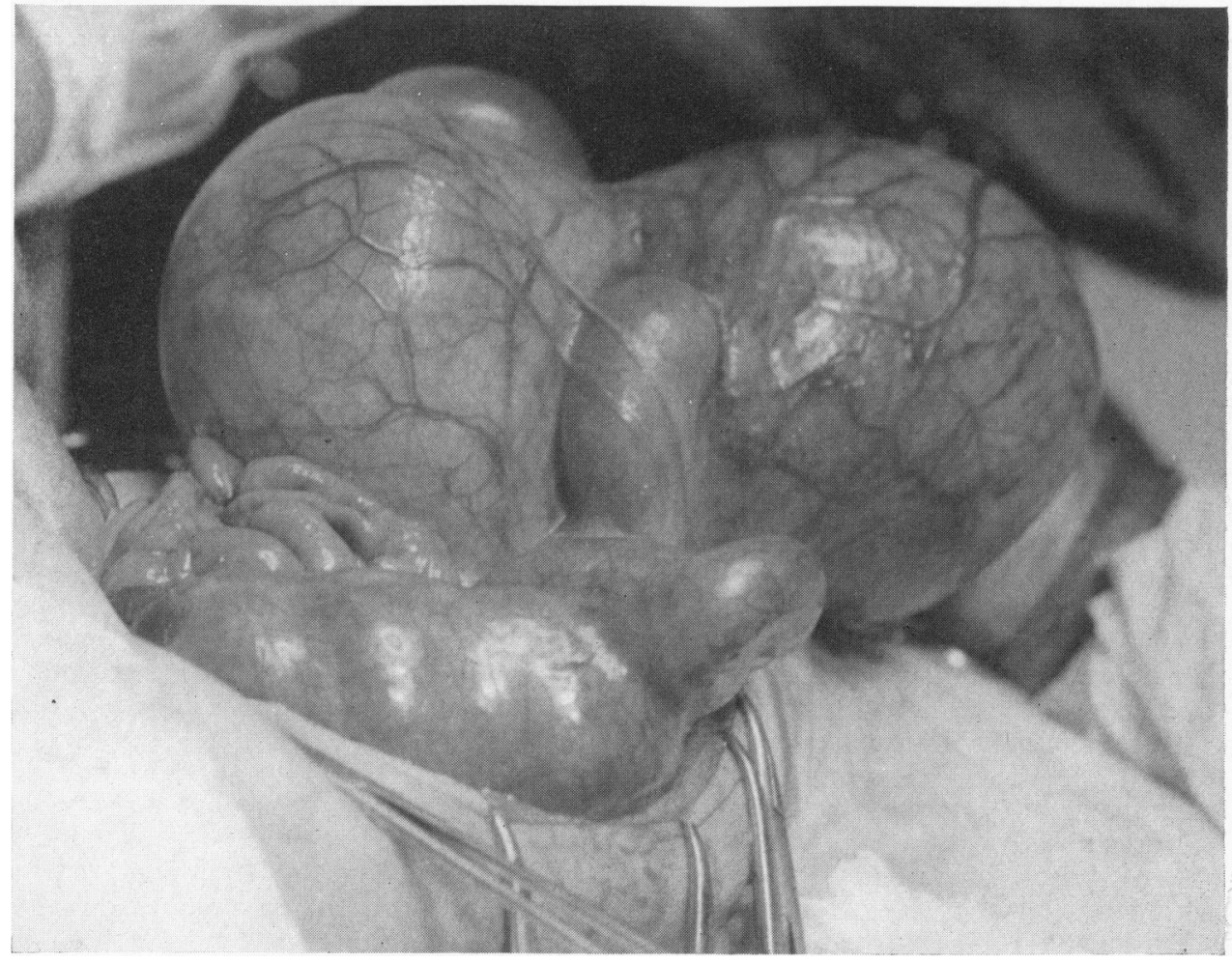


moderately dilated. The rent in the bladder was repaired and subsequently the obstructing valves in the posterior urethra were removed. The child is now 5 years old and perfectly healthy.

The results of suprapubic cystostomy in newborn infants were, therefore, not satisfactory. In older children the results were slightly better (Table 3 ). There were six such children. In three, primary suprapubic cystostomy was followed after some time by operative relief of the obstruction (Cases 11,12 and 13). One died of pyelonephritis, and in the other two the initial urinary infection became worse and necessitated nephrostomy in one and nephro-ureterectomy in the other. These cases illustrate that the main danger of suprapubic cystostomy is exacerbation of the urinary infection that is invariably present. In these advanced cases antibiotics will not cure the urinary infection because pools of stagnating urine remain in the chronically distended and fibrosed bladder and the numerous diverticula. The presence of the drainage tube aggravates the infection. In two children (Cases 14 and 15) bilateral cutaneous ureterostomies were carried out some months after the cystostomies. This finally cured the infection and preserved what little functioning renal tissue was left.

These poor results of suprapubic cystostomy are somewhat surprising in view of the fact that some surgeons routinely employ this operation to drain

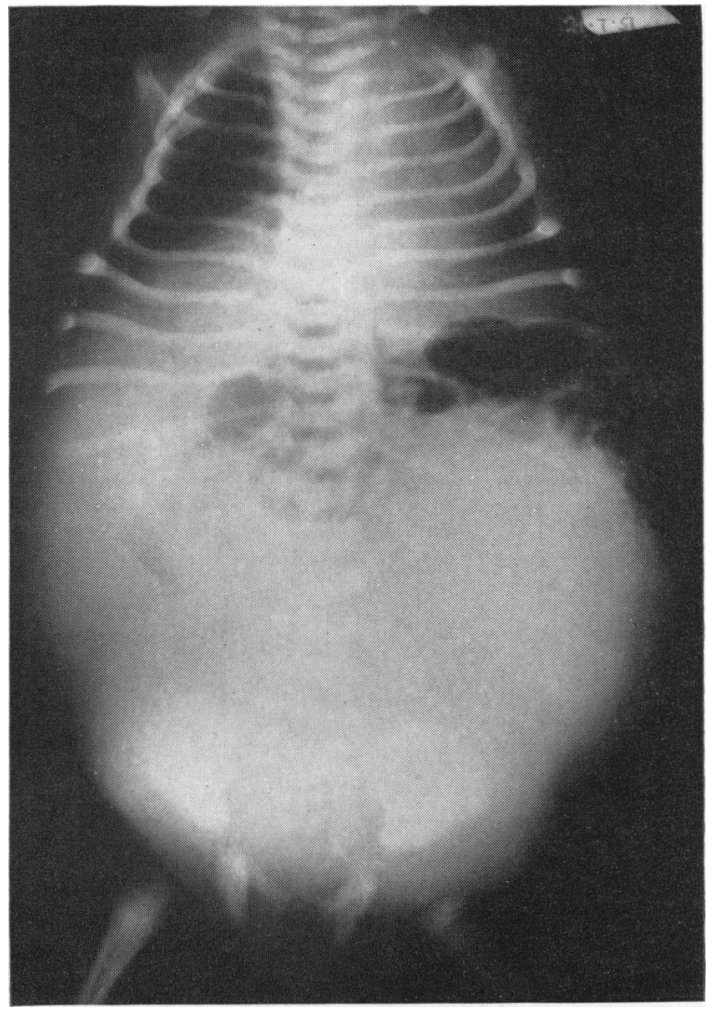

Fig. 4.-Radiograph of Case 10, showing abdominal distension to be due to fluid (urine in the peritoneal cavity).

TABLE 3

SUPRAPUBIC CYSTOSTOMY IN OLDER CHILDREN

\begin{tabular}{|c|c|c|c|c|c|c|c|c|}
\hline Case & Sex & Age & $\begin{array}{l}\text { Presenting } \\
\text { Symptoms }\end{array}$ & $\begin{array}{l}\text { Blood Urea } \\
\text { (mg./100 ml.) }\end{array}$ & Infection & Pathology & Treatment & Follow-up \\
\hline 11 & Female & 3 years & $\begin{array}{l}\text { Overflow incon- } \\
\text { tinence }\end{array}$ & 43 & $++E$. coli & $\begin{array}{l}\text { Neurogenic } \\
\text { bladder }\end{array}$ & Suprapubic & $\begin{array}{l}\text { One month later open } \\
\text { resection; pyelo- } \\
\text { nephritis, uraemia; } \\
\text { death }\end{array}$ \\
\hline 12 & Male & 5 years & Incontinence & 38 & + E. coli & Valves & Suprapubic & $\begin{array}{l}\text { Four weeks later } \\
\text { nephrostomy, re- } \\
\text { section of valves; } \\
\text { well }\end{array}$ \\
\hline 13 & Male & $2 \frac{1}{2}$ years & $\begin{array}{l}\text { Incontinence; } \\
\text { recurrent } \\
\text { urinary in- } \\
\text { fections }\end{array}$ & 54 & ++ Proteus & 'Bladder neck' & Suprapubic & $\begin{array}{l}\text { Two months later } \\
\text { transurethral re- } \\
\text { section; persistent } \\
\text { infection; right } \\
\text { nephro-ureterec- } \\
\text { tomy; well }\end{array}$ \\
\hline 14 & Female & 7 months & Uraemia & 97 & + E. coli & 'Bladder neck' & Suprapubic & $\begin{array}{l}\text { Infection worse; three } \\
\text { months later ureter- } \\
\text { ostomy; well }\end{array}$ \\
\hline 15 & Male & 8 years & Enuresis & 35 & None & $\begin{array}{l}\text { Valves; one kid- } \\
\text { ney only }\end{array}$ & Suprapubic & $\begin{array}{l}\text { Infection worse; one } \\
\text { month later ureter- } \\
\text { ostomy; well }\end{array}$ \\
\hline 16 & Female & 6 years & $\begin{array}{l}\text { Incontinence; } \\
\text { uraemia }\end{array}$ & 600 & +++ E. coli & 'Bladder neck' & $\begin{array}{l}\text { Suprapubic; } \\
\text { intravenous } \\
\text { antibiotic; } \\
\text { Bull's regime }\end{array}$ & $\begin{array}{l}\text { Recurring improve- } \\
\text { ments and relapses; } \\
\text { blood urea between } \\
43 \text { and } 800 \text { mg./100 } \\
\text { ml.; death in urae- } \\
\text { mia two and a half } \\
\text { years later }\end{array}$ \\
\hline
\end{tabular}


TABLE 4

PRIMARY TUBELESS CYSTOSTOMY

\begin{tabular}{|c|c|c|c|c|c|c|c|c|}
\hline Case & Sex & Age & $\begin{array}{l}\text { Presenting } \\
\text { Symptoms }\end{array}$ & $\begin{array}{l}\text { Blood Urea } \\
\text { (mg./100 ml.) }\end{array}$ & Infection & Pathology & Treatment & Follow-up \\
\hline 17 & Female & 2 months & $\begin{array}{l}\text { Overflow incon- } \\
\text { tinence }\end{array}$ & 54 & None & $\begin{array}{l}\text { Neurogenic } \\
\text { bladder }\end{array}$ & $\begin{array}{l}\text { Tubeless } \\
\text { cystostomy }\end{array}$ & $\begin{array}{l}\text { Drained well; moder- } \\
\text { ate infection; death } \\
\text { seven months later } \\
\text { of meningitis }\end{array}$ \\
\hline 18 & Male & 3 years & $\begin{array}{l}\text { Failure to thrive; } \\
\text { dribbling }\end{array}$ & 35 & None & $\begin{array}{c}\text { Duplication } \\
\text { urethra }\end{array}$ & $\begin{array}{l}\text { Tubeless } \\
\text { cystostomy }\end{array}$ & $\begin{array}{l}\text { No improvement in } \\
\text { general condition; } \\
\text { loop ureterostomies }\end{array}$ \\
\hline
\end{tabular}

TABLE 5

PRIMARY NEPHROSTOMY

\begin{tabular}{|c|c|c|c|c|c|c|c|c|}
\hline Case & Sex & Age & $\begin{array}{l}\text { Presenting } \\
\text { Symptoms }\end{array}$ & $\begin{array}{l}\text { Blood Urea } \\
\text { (mg./100 ml.) }\end{array}$ & Infection & Pathology & Treatment & Follow-up \\
\hline 19 & Male & 11 months & $\begin{array}{l}\text { Vomiting; recur- } \\
\text { rent urinary } \\
\text { infections }\end{array}$ & 77 & $++E$. coli & Valves & $\begin{array}{l}\text { Right nephro- } \\
\text { stomy (left } \\
\text { kidney func- } \\
\text { tionless) }\end{array}$ & $\begin{array}{l}\text { Pyelonephritis, urae- } \\
\text { mia; death after } \\
\text { one week }\end{array}$ \\
\hline 20 & Male & $3 \frac{1}{2}$ years & $\begin{array}{c}\text { Dysuria; fre- } \\
\text { quency; fail- } \\
\text { ure to thrive }\end{array}$ & 100 & $+++E \cdot$ coli & $\begin{array}{r}\text { 'Bladder neck'; } \\
\text { rectal atresia }\end{array}$ & $\begin{array}{l}\text { Bilateral nephro- } \\
\text { stomies }\end{array}$ & $\begin{array}{l}\text { Persistent urinary } \\
\text { infection, seven } \\
\text { months later trans- } \\
\text { urethral resection; } \\
\text { blood urea } 160 \mathrm{mg} \text {./ } \\
100 \mathrm{ml} \text {.; 'not well' }\end{array}$ \\
\hline 21 & Female & 2 years & Uraemia & 120 & +++ E. coli & $\begin{array}{l}\text { Cloaca; one } \\
\text { kidney only }\end{array}$ & Nephrostomy & $\begin{array}{l}\text { Worse; three weeks } \\
\text { later ureterostomy; } \\
\text { well for five years }\end{array}$ \\
\hline
\end{tabular}

the bladder in advanced cases of lower urinary obstruction (Conger and Toub, 1960). In our experience it is a bad operation, but it must be admitted that some children with very advanced urinary obstruction will survive it for prolonged periods, as is illustrated by the last case in the group (Case 16). This girl was comatose when admitted with advanced uraemia, a blood urea of $600 \mathrm{mg}$./ $100 \mathrm{ml}$, and urine composed of thick pus. Following suprapubic cystostomy, vigorous antibiotic treatments and Bull's régime for her uraemia, she recovered and was discharged from hospital with her suprapubic tube still in situ. For the next two and a half years she was in and out of hospital with recurrent attacks of pyelonephritis, anuria, uraemia, etc. Occasionally her blood urea would fall as low as $100 \mathrm{mg}$./100 ml., at one time it rose to 800 $\mathrm{mg} . / 100 \mathrm{ml}$. She finally died in one of the attacks and at autopsy only microscopic islands of functioning renal tissue were discovered.

As the indwelling suprapubic catheter aggravates urinary infection, it might be thought that a tubeless cystostomy would be the procedure of choice (Carlson, 1960). This operation was carried out in a further two cases, but the results were not impressive (Table 4). Urinary infection did not become a grave problem, but the chronically distended bladders failed to empty completely. This necessitated nursing the children prone, lying on a frame. One child (Case 17) died of meningitis, the other (Case 18) only improved after ureterostomies were performed. It must also be mentioned that the operation is quite an extensive one in a severely ill child. Even a large bladder will not reach the anterior abdominal wall without tension, unless it is extensively mobilized by opening the peritoneum.

Nephrostomies are frequently employed in order to drain the chronically distended urinary tract, but in our experience they have not been very successful (Table 5). Leakage from permanent nephrostomies is very difficult to control, and the presence of a drainage tube in the dilated pelvis promotes urinary infection. Furthermore, a bilateral nephrostomy in an ill uraemic patient is often quite an undertaking. Three patients were treated by nephrostomies. In one, the pyelonephritis was aggravated and he died (Case 19). In the other two, urinary infection persisted or became worse and only improved after removal of the nephrostomy tubes and after performing cutaneous ureterostomies.

Transplantation of the ureters into an isolated ileal loop is, in our experience, a very satisfactory procedure for children with paralysed bladders secondary to myelomeningoceles (Rickham, 1956). In children with gross trabeculation of the bladder, vesical diverticula formation, hydro-ureters, hydro- 
TABLE 6

PRIMARY TRANSPLANTATION OF URETERS INTO ISOLATED ILEAL LOOP

\begin{tabular}{|c|c|c|c|c|c|c|c|c|}
\hline Case & Sex & Age & $\begin{array}{l}\text { Presenting } \\
\text { Symptoms }\end{array}$ & $\begin{array}{c}\text { Blood Urea } \\
\text { (mg./100 ml.) }\end{array}$ & Infection & Pathology & Treatment & Follow-up \\
\hline 22 & Male & 9 years & Uraemia & 200 & +++ E. coli & Valves & Loop & Anuria; death \\
\hline 23 & Female & 6 months & $\begin{array}{l}\text { Recurrent urin- } \\
\text { ary infections }\end{array}$ & 58 & $+\underset{\text { Pyocyaneus }}{+}$ & Cloaca & Loop & $\begin{array}{l}\text { Uraemia, infarction } \\
\text { of loop; death }\end{array}$ \\
\hline
\end{tabular}

There were two fatal cases where ileal loop followed primary removal of obstruction.

TABLE 7

PRIMARY URETEROSTOMIES

\begin{tabular}{|c|c|c|c|c|c|c|c|c|}
\hline Case & Sex & Age & $\begin{array}{l}\text { Presenting } \\
\text { Symptoms }\end{array}$ & $\begin{array}{l}\text { Blood Urea } \\
\text { (mg./100 ml.) }\end{array}$ & Infection & Pathology & Treatment & Follow-up \\
\hline 24 & Male & 7 days & Vomiting & 178 & +++ E. coli & Valve & $\begin{array}{l}\text { Bilateral ureter- } \\
\text { ostomies }\end{array}$ & Much improved \\
\hline 25 & Male & 6 weeks & $\begin{array}{l}\text { Failure to thrive; } \\
\text { urinary infec- } \\
\text { tion }\end{array}$ & 79 & +++ E. coli & $\begin{array}{l}\text { Rectal atresia, } \\
\text { 'bladder } \\
\text { neck'; one } \\
\text { kidney only }\end{array}$ & $\begin{array}{l}\text { Loop ureter- } \\
\text { ostomies }\end{array}$ & $\begin{array}{l}\text { Remarkable improve- } \\
\text { ment of moribund } \\
\text { patient }\end{array}$ \\
\hline 26 & Male & 12 years & $\begin{array}{l}\text { Dysuria, } \\
\text { enuresis }\end{array}$ & 98 & $\begin{array}{l}+\underset{\text { ? T.B.; coli }}{++} \\
\text { staph. }\end{array}$ & $\begin{array}{l}\text { T.B.; stricture } \\
\text { urethra; one } \\
\text { functioning } \\
\text { kidney only }\end{array}$ & $\begin{array}{l}\text { Ureterostomy, } \\
\text { antibiotics }\end{array}$ & $\begin{array}{l}\text { Very well three years } \\
\text { later }\end{array}$ \\
\hline 27 & Male & 5 years & $\begin{array}{l}\text { Overflow incon- } \\
\text { tinence }\end{array}$ & 72 & +++ Proteus & $\begin{array}{l}\text { Neurogenic } \\
\text { bladder; one } \\
\text { functioning } \\
\text { kidney only }\end{array}$ & Ureterostomy & $\begin{array}{l}\text { One year later nephro- } \\
\text { ureterectomy; well } \\
\text { for over two years }\end{array}$ \\
\hline 28 & Male & 9 years & $\begin{array}{l}\text { Overflow incon- } \\
\text { tinence }\end{array}$ & 170 & None & $\begin{array}{c}\text { Neurogenic } \\
\text { bladder }\end{array}$ & $\begin{array}{l}\text { Bilateral } \\
\text { ureterostomy }\end{array}$ & $\begin{array}{l}\text { Improved for one } \\
\text { year; then urinary } \\
\text { infection, renal } \\
\text { failure; death after } \\
\text { two years }\end{array}$ \\
\hline
\end{tabular}

There were six additional cases with secondary ureterostomies.

nephroses and uraemia, transplantation of the ureters into an isolated ileal loop is too extensive an operation, and our results have been poor. In two children the operation was carried out as a primary procedure (Table 6, Cases 22 and 23); in two as a secondary procedure (Table 8, Cases 32 and 33); only one survived.

The beneficial effects of cutaneous ureterostomies in children with advanced lower urinary obstruction have already been mentioned. This operation was carried out in six cases as a secondary procedure (Cases 9, 14, 18, 21, 33 and 34) with only one death. Primary ureterostomies were performed in a further five patients with one fatality (Table 7). This is gratifying as several of these patients were moribund at the time of operation. Fortunately the operation is a very minor one. In most of these cases the ureters are so long and tortuous that loop ureterostomies can be carried out (Fig. 5). The great disadvantage of this operation is that the patient is left with two orifices discharging urine, and fitting two urinary bags is a most unsatisfactory procedure. Because of the length of the ureters it is usually possible to bring them to the surface as end ureterostomies lying side by side in the midline below the umbilicus. This can be done as a primary procedure (Johnston and Rickham, 1958; Swenson and Smyth, 1959), or following initial loop uretero-

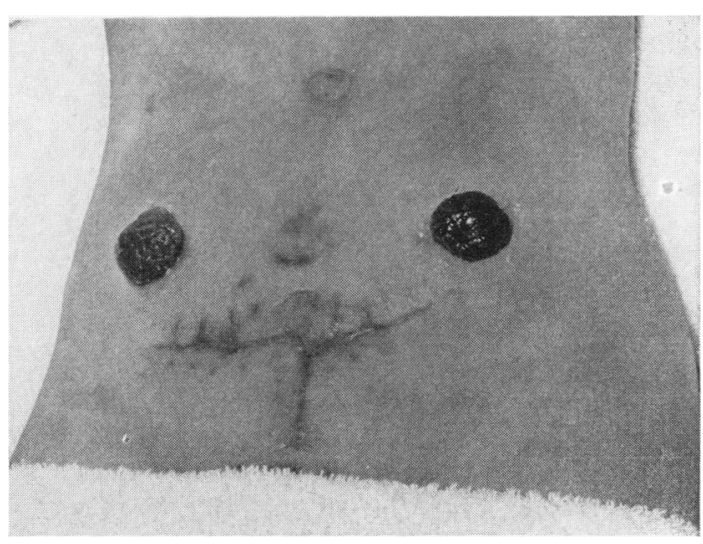

Fro. 5.-Bilateral loop ureterostomies in a boy, 10 years of age. 


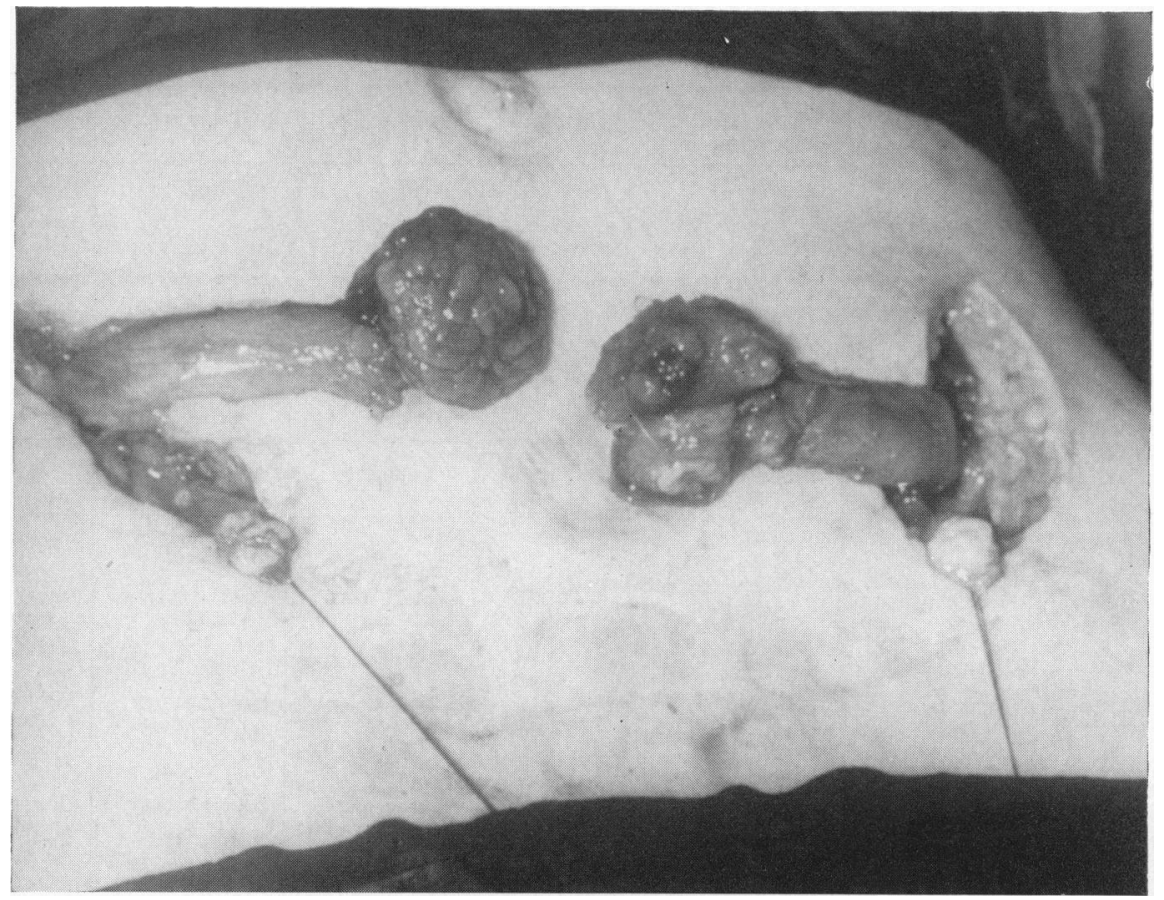

Fig. 6.-Same case as Fig. 5. The segment proximal to the loop ureterostomy has been mobilized. The distal ureter can be seen in the lower corner of the wounds, tied and divided. The great length of the proximal ureter is noticeable.

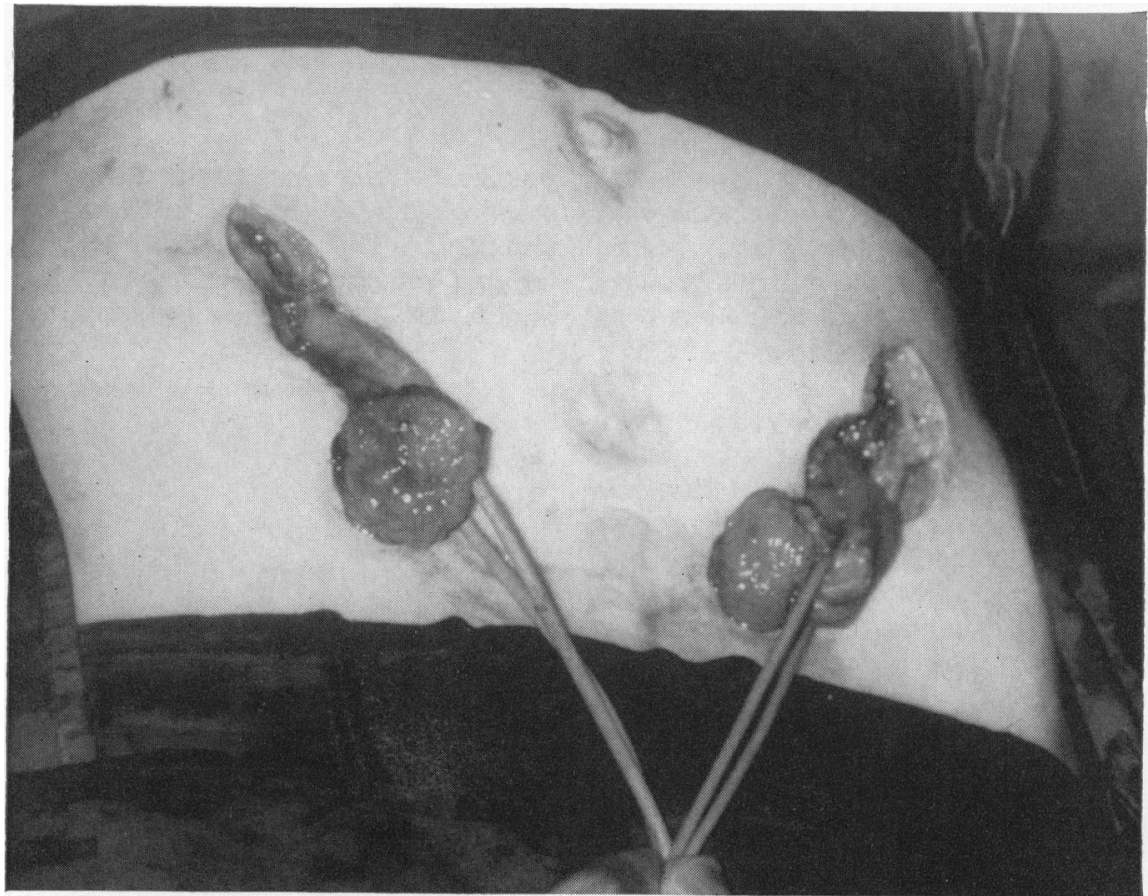

FIG. 7.-Same case as Fig. 6. The mobilized proximal ureters are of adequate length to allow their distal end to be brought out side by side in the midline. 
TABLE 8

SURGICAL RELIEF OF ADVANCED LOWER URINARY OBSTRUCTION

\begin{tabular}{|c|c|c|c|c|c|c|c|c|}
\hline Case & Sex & Age & $\begin{array}{l}\text { Presenting } \\
\text { Symptoms }\end{array}$ & $\begin{array}{l}\text { Blood Urea } \\
\text { (mg./100 ml.) }\end{array}$ & Infection & Pathology & Treatment & Follow-up \\
\hline 29 & Male & 3 years & $\begin{array}{l}\text { Recurrent urin- } \\
\text { ary infections }\end{array}$ & 31 & + E. coli & 'Bladder neck' & $\begin{array}{l}\text { Transurethral } \\
\text { resection and } \\
\text { cystostomy }\end{array}$ & $\begin{array}{l}\text { Pyelonephritis; blood } \\
\text { urea rose to } 200 \\
\text { mg./100 ml.; death }\end{array}$ \\
\hline 30 & Male & 5 years & $\begin{array}{l}\text { Abdominal dis- } \\
\text { tension; renal } \\
\text { dwarfism }\end{array}$ & 120 & $+++E \cdot$ coli & Valves & $\begin{array}{l}\text { Transurethral } \\
\text { resection and } \\
\text { cystostomy }\end{array}$ & $\begin{array}{l}\text { Persistent urinary in- } \\
\text { fection; diverticul- } \\
\text { ectomy; uraemia; } \\
\text { death }\end{array}$ \\
\hline 31 & Male & 10 months & $\begin{array}{l}\text { Recurrent urin- } \\
\text { ary infections }\end{array}$ & 100 & +++ E. coli & Valves & $\begin{array}{c}\text { Transurethral } \\
\text { resection }\end{array}$ & $\begin{array}{l}\text { Pyelonephritis; } \\
\text { septicaemia; death }\end{array}$ \\
\hline 32 & Male & 2 years & $\begin{array}{l}\text { Urinary infec- } \\
\text { tions; } \\
\text { dribbling }\end{array}$ & 92 & None & 'Bladder neck' & $Y \cdot V$ resection & $\begin{array}{l}\text { No improvement; } \\
\text { three months later } \\
\text { ileal loop; post- } \\
\text { operative leak; } \\
\text { death }\end{array}$ \\
\hline 33 & Female & 1 year & $\begin{array}{l}\text { Overflow incon- } \\
\text { tinence }\end{array}$ & 130 & +++ Proteus & $\begin{array}{c}\text { Neurogenic } \\
\text { bladder }\end{array}$ & $\begin{array}{c}\text { Transurethral } \\
\text { resection }\end{array}$ & $\begin{array}{l}\text { Seven months later } \\
\text { ileal loop }\end{array}$ \\
\hline 34 & Male & 3 years & $\begin{array}{l}\text { Urinary infec- } \\
\text { tion; abdomi- } \\
\text { nal distension }\end{array}$ & 152 & ++ Proteus & 'Bladder neck' & $\begin{array}{l}\text { Open resection } \\
\text { and supra- } \\
\text { pubic cysto- } \\
\text { stomy }\end{array}$ & $\begin{array}{l}\text { No improvement; one } \\
\text { month later nephro- } \\
\text { stomy; no improve- } \\
\text { ment; two months } \\
\text { later ureterosto- } \\
\text { mies; great im- } \\
\text { ment }\end{array}$ \\
\hline 35 & Male & 6 years & Dribbling & 59 & None & Valves & $\begin{array}{c}\text { Transurethral } \\
\text { resection }\end{array}$ & $\begin{array}{l}\text { Five years later renal } \\
\text { failure; loop uret- } \\
\text { erostomies; marked } \\
\text { improvement }\end{array}$ \\
\hline 36 & Male & $4 \frac{1}{2}$ years & $\begin{array}{c}\text { Recurrent urin- } \\
\text { ary infection }\end{array}$ & 150 & +++ E. coli & 'Bladder neck' & Open resection & $\begin{array}{l}\text { Progressive renal } \\
\text { failure; renal ric- } \\
\text { kets; after nine } \\
\text { years, rapidly de- } \\
\text { teriorating; kidney } \\
\text { homotransplant; } \\
\text { death }\end{array}$ \\
\hline
\end{tabular}

stomies (Figs. 6 and 7). Fitting one urinary bag to these midline ureterostomies is quite satisfactory and indwelling tubes can, therefore, be dispensed with. Stenosis of the ureterostomies occasionally occurs, but can easily be rectified.

Group III consists of patients with lower urinary obstruction which was removed by operation without benefit to the patient (Table 8). In retrospect, the removal of the obstruction as a primary procedure was undoubtedly a mistake. The patients either died as the result of the operation or their general condition did not improve and necessitated further operations under even less favourable circumstances.

There were eight cases in this group. In three (Cases 29, 30 and 31), removal of the obstruction in the presence of latent uraemia and urinary infection resulted in death due to virulent pyelonephritis. Two cases with spinal bladders have already been mentioned (Cases 32 and 33). Both suffered from overflow incontinence with back pressure. In both children a wedge resection of the bladder neck was carried out to enable the mother to express the bladder with ease. In both, the hydro-ureters and hydronephroses gradually increased in size. Transplantation of the ureters into an isolated ileal loop was carried out under extremely unfavourable conditions, and only one of the children survived.

In two children failure of the bladder to contract sufficiently and to empty after removal of the obstructing lesion necessitated further 'decompression' operations. One of these cases (Case 35) is instructive. This boy of 6 years of age had valves in the posterior urethra with a grossly distended and trabeculated bladder and multiple vesical diverticulae (Fig. 8). The valves were removed by endoscopic resection. He was then able to empty his bladder nearly completely, the residual urine being $20 \mathrm{ml}$., and he was discharged. He failed to attend the follow-up clinic and was readmitted to hospital five years later with uraemia (Fig. 9). Bilateral cutaneous loop ureterostomy saved his life and cured his severe urinary infection. Subsequent exploration of the bladder and prostatic urethra showed that there was now no trace of an obstruction in the posterior urethra and that the bladder was enormously dilated, thin-walled and the walls entirely 


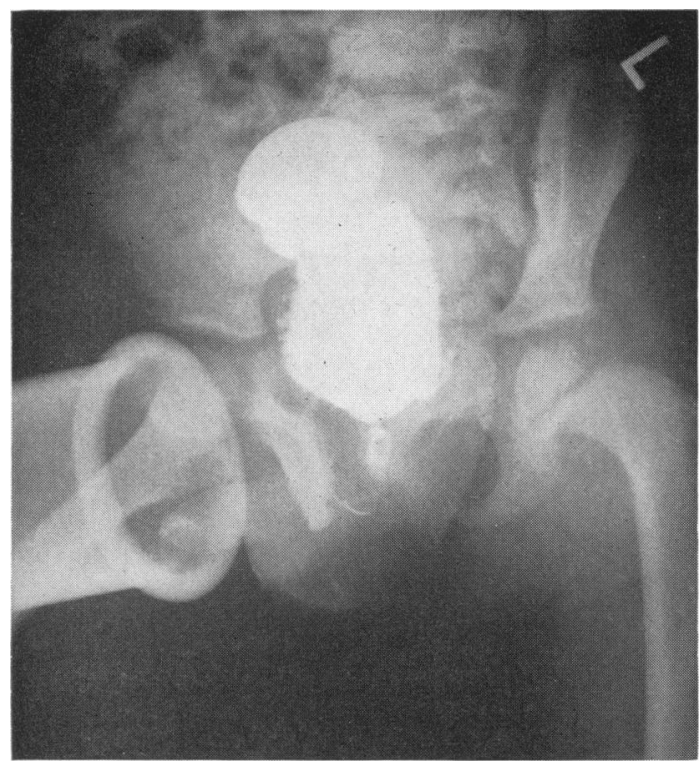

FIG. 8.-Case 35 : pre-operative micturating cysto-urethrogram.

composed of fibrous tissue with numerous diverticulae. The bladder had lost all contractile power.

This case shows once again that in advanced

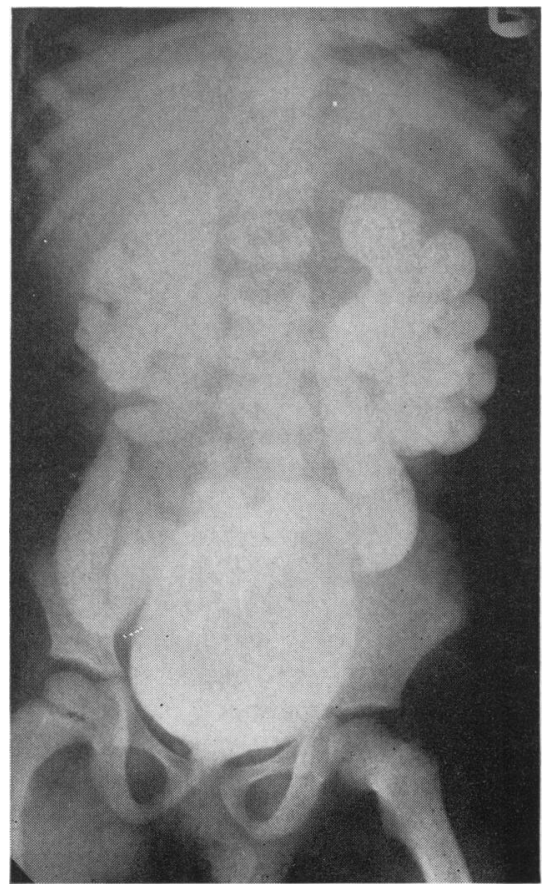

Fig. 9.-Case 35: Cystogram five years after successful removal of urethral valves. Note reflux up both ureters. lesions even the successful removal of the obstruction will not lead to a cure. Children who have had too much of their renal tissue destroyed may go on living for long periods in relative health, but will finally succumb, because the diminished renal tissue cannot cope with the strains imposed upon it by growth and especially by puberty. These children need new kidneys, nothing else will be of any avail. The last case (Case 36) is an illustration. An open bladder-neck resection was performed when the patient was $4 \frac{1}{2}$ years old. At the time he had marked hydro-ureters and hydronephroses and was in renal failure. He was subsequently able to empty his bladder completely, but his blood urea always remained elevated above $100 \mathrm{mg}$./ $100 \mathrm{ml}$. His general condition remained surprisingly good at first, but when he was 13 years of age he developed severe renal rickets and subsequently his general condition went rapidly downhill. It was obvious that he had only a few more months to live. In view of this, it was decided to perform a renal homotransplant under cortisone and 17mercaptopurine cover (Fig. 10). This operation was, however, not more successful than previous attempts, and the patient finally died of septicaemia.

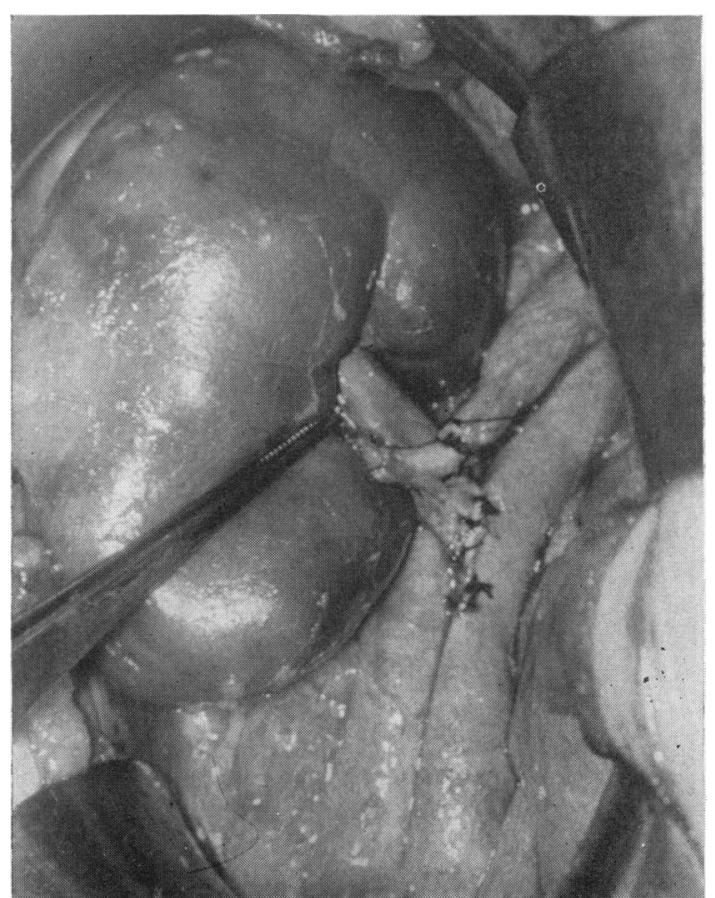

Fig. 10.-Case 36: Homotransplant of left kidney lying retroperitoneally in right iliac fossa. The renal artery is anastomosed end to end to the right internal iliac artery and the renal vein end to side to the right external iliac vein. 
The ultimate fate of some of the children with advanced degrees of lower urinary obstruction is, therefore, still rather depressing. Unfortunately, earlier diagnosis of the condition is frequently not feasible, as many of the most advanced cases are seen in the neonatal period.

\section{Summary}

During the past 10 years 77 children with lower urinary obstruction were admitted to the surgical wards of the two Liverpool Children's Hospitals. In 41 children the obstruction was successfully removed. In 36 children the advanced effects of the back pressure made primary removal of the obstruction either impossible or inadvisable. There were 20 deaths amongst these children. The advanced cases are discussed in some detail.
I should like to thank Dr. G. Brandesky for his help in collecting the case material, and my colleagues, Miss Isabella Forshall and Mr. J. H. Johnston, for allowing me to include some of their cases.

\section{REFERENCES}

Baker, R., Tehan, T. and Kelly, T. (1960). Observations on 100 children with bladder neck obstruction. J. Urol. (Baltimore), 84, 334.

Carlson, H. E. (1960). Tubeless cystotomy in childhood. ibid., 83,669 .

Conger, K. B. and Toub, L. (1960). Obstruction of the bladder neck in the male infant and child. J. Pediat., 57, 855.

Deakin, R. (1957). Congenital bladder neck obstruction in children. J. Urol. (Baltimore), 78, 384.

Johnston, J. H. and Rickham, P. P. (1958). Complications following uretero-ileostomy in childhood and the use of cutaneous uretero-ileostomy in childhood and the use of cutaneo
ureterostomy in advanced lesions. Brit. J. Urol., 30, 437.

Leadbetter, G. W. and Leadbetter, W. F. (1959). Diagnosis and treatment of congenital bladder-neck obstruction in children. New Engl. J. Med., 260, 633.

Rickham, P. P. (1956). The use of the isolated ileal loop in paediatric urology. Brit. J. Urol., 28, 394

Swenson, O and Smyth, B. T. (1959). Aperistaltic megaloureter; treatment by bilateral cutaneous ureterostomy using a new technique: preliminary communication. J. Urol. (Baltimore), technique 62 .
82, 